\title{
A EXECUÇÃO DA PENA E SEUS PERCALÇOS JURÍDICOS
}

\author{
PENALTY ENFORCEMENT AND ITS LEGAL OBSTACLES
}

\author{
Bruna Yara Decarli ${ }^{1}$ \\ Doroteu Trentini Zimiani²
}

Graduanda em Direito pela Universidade Paranaense - UNIPAR - Umuarama - PR. E-mail: bruna.de.carli@hotmail.com

${ }^{2}$ Bacharel em Direito/UNIPAR, Especialista em Docência do Ensino Superior/UNIPAR e Mestre em Direito Processual Contemporâneo e Cidadania/UNIPAR. Atualmente é Advogado e Supervisor de Estágio em Processo Penal/UNIPAR.

E-mail: doroteuzimiani@uol.com.br
Recebido em dezembro de 2016 Aceito em abril de 2017
DECARLI, B. Y.; ZIMIANI, D. T. A execução da pena e seus percalços jurídicos. Akrópolis Umuarama, v. 26, n. 2, p. 97-108, jul./dez. 2018.

DOI: 10.25110/akropolis.v26i2.7454

Resumo: Diante da necessidade de normatização específica acerca da problemática que envolve a execução penal, em 11 de julho de 1984, o legislador instituiu a Lei de Execução Penal $n^{\circ} 7.210$, com o objetivo de estabelecer diretrizes para atendimento das disposições da sentença ou decisão criminal e proporcionar condições para a integração social do preso e do internado, impondo deveres ao Estado. Contudo, a situação do sistema penal brasileiro, apresenta-se como um dos grandes obstáculos para a aplicação dos preceitos contidos na lei. A superlotação dos presídios e cadeias e a falta de políticas públicas que busquem medidas alternativas ao encarceramento, acabam frustrando o processo de reabilitação do apenado, desencadeando na sociedade um sentimento de rejeição quanto a esse indivíduo e influenciando o seu retorno à criminalidade. A adoção de um modelo de execução penal garantista seria a solução para esse sistema falido, no qual o Poder Executivo, em unidade de propósitos com os operadores do direito, atuariam de maneira conjunta no emprego de melhorias ao processo executivo, promovendo-se a satisfação da pretensão punitiva estatal buscada na sentença e assegurando ao apenado todos os seus direitos e garantias constitucionais elencados na LEP, de maneira a suprir suas carências. A reincidência criminal somente será elidida quando o Estado possibilitar meios para a reabilitação e ressocialização do apenado.

Palavras-chave: Devido Processo Legal; Execução Penal Garantista; Lei de Execução Penal; Reincidência.

ABSTRACT: Given the need for specific standardization regarding the issue involving criminal enforcement, on 11 July 1984, the legislator instituted the Law of Criminal Enforcement No. 7210, with the purpose of establishing guidelines to comply with the provisions of the criminal ruling or decision and provide conditions for the social integration of the prisoner or intern, imposing duties to the State. However, the situation of the Brazilian Criminal System is one of the great obstacles for the application of the provisions set forth in the law. The overcrowding of prisons and jails and the lack of public policies that seek alternative measures related to imprisonment frustrate the rehabilitation process of the imprisoned individual, promoting a rejection feeling in the society towards that individual and thus influencing his/her return to criminality. The adoption of a guarantee penal enforcement would be the solution for this failing system, where the Executive Power, together with law enforcement operators in purpose units, would jointly act to apply improvements in the executive procedure, promoting the satisfaction of the punitive intention and constitutional guarantees listed in the CE Law, so as to meet its needs. The criminal recurrence will only be possible when the State enables means for the rehabilitation and resocialization of the penalized individual.

Keywords: Criminal Enforcement Law; Guarantee Penal Enforcement; Legal Due Process; Recurrence. 


\section{INTRODUÇÃO}

Com o trânsito em julgado de sentença condenatória, encerra-se o processo de conhecimento e instala-se uma nova relação jurídica a partir de formação de um título executório penal - a sentença - na qual o magistrado e o representante do Ministério Público passam a exercer papéis principais para a satisfação de pretensão punitiva, com a efetivação do comando da decisão condenatória prolatada. De nada vale a imposição de uma reprimenda ao agente praticante de uma conduta delituosa, se o processo de execução penal for falho e não possibilitar a reabilitação do agente.

A Lei de Execução Penal no 7.210 (LEP), criada em 11 de julho de 1984, é considerada uma das mais completas do mundo, uma vez que possui um conjunto de preceitos e obrigações perfeitamente elaborados para o estabelecimento de uma execução penal garantidora dos direitos indisponíveis dos jurisdicionados, em consonância com os princípios fundamentais assegurados em nossa Carta Magna. A LEP estabelece o Estado como o garantidor, que intervirá de maneira incisiva e constante.

Contudo, por mais inovadora que a lei seja, ela falha potencialmente, vez que a omissão do Estado ante a crise do sistema prisional brasileiro e ausência de políticas públicas voltadas para esse mister, apresentam-se como entrave para preceitos legais sejam atendidos.

Desse modo, o encargo acaba recaindo ao juiz da execução e ao Ministério Público, que impulsionados a atuar como fiscais e promotores da justiça penal, devem garantir um processo executivo mais individualizado possível ao reeducando, para que se possa cogitar de sua possível recuperação e, concomitantemente, a satisfação a pretensão punitiva estatal.

A omissão do Estado ante a decadência do sistema penal brasileiro e a ausência de políticas públicas voltadas para o reparo do impacto gerado pelas mazelas desse sistema, que ao invés de reabilitar o apenado, acaba por vinculá-lo ainda mais à criminalidade, demonstram que a legitimação do jus puniendi do Estado está convergindo com os preceitos estabelecidos pela Lei de Execução Penal.

Diante disso, o presente estudo objetiva demonstrar a necessidade da atuação conjunta do Poder Executivo com os operadores do Direito, como garantidores de uma efetiva execução penal, observando os fatores da reincidência criminal face as mazelas do sistema prisional brasileiro e descaso do poder estatal. Para tanto, neste estudo foi utilizada a modalidade de pesquisa bibliográfica, na tentativa de resolver a problemática, a partir de referência teórica, com a análise da literatura disponível.

\section{A FINALIDADE DA LEI DE EXECUÇÃO PE- NAL}

Com a certificação do trânsito em julgado da sentença condenatória, acredita-se que estaria satisfeita a pretensão estatal. Em verdade, é na fase executória que se alcança a verdadeira satisfação, com o correto cumprimento da pena. Nesse sentido, leciona Mirabete (2007, p. 32): "A justiça penal não termina com o trânsito em julgado da sentença condenatória, mas realiza-se principalmente na execução".

A pena é uma condição estabelecida pelo Estado, por meio da qual se busca a punição do agente praticante de uma conduta delituosa e sua reeducação para o retorno em sociedade.

Conforme Santos (1998, p. 13): "A Execução Penal tem por finalidades básicas tanto o cumprimento efetivo da sentença condenatória como a recuperação do sentenciado e o seu retorno à convivência social". E, para que o cumprimento da reprimenda imposta ocorra, o processo de execução deve ser desenvolvido da maneira mais ordenada e fiscalizada possível pelos órgãos da execução.

Consoante o disposto no artigo $1^{\circ}$ da Lei $n^{\circ}$ 7.210/84 (BRASIL, 1984): "A execução penal tem por objetivo efetivar as disposições de sentença ou decisão criminal e proporcionar condições para a harmônica integração social do condenado e do internado."

À vista disso, vale ressaltar que, inobstante o disparate entre a intenção da lei e a realidade do sistema penal brasileiro, os condenados vivem sob o pálio do Princípio Constitucional da Dignidade da Pessoa Humana que norteia todo o ordenamento jurídico brasileiro, garantindo aos presos uma série de direitos inalienáveis, dentre eles a garantia do devido processo legal e dos direitos do contraditório e ampla defesa previstos no art, $5^{\circ}$, caput, inciso LIV e LV, da Constituição Federal. Nesse sentido, afirma Marcão (2005, p.1):

A execução penal deve objetivar a inte- 
gração social do condenado ou do internado, já que adotada a teoria mista ou eclética, segundo o qual a natureza retributiva da pena não busca apenas a prevenção, mas também a humanização. Objetiva-se, por meio da execução, punir e humanizar.

Infere-se da exposição de motivos $n^{\circ}$ 213, de 9 de maio de 1983, que da Lei de Execução Penal foi concebida sob a luz do Princípio Constitucional da Dignidade da Pessoa Humana, de maneira a assegurar ao condenado e ao internado e também ao egresso, todos os direitos não atingidos pela sentença ou pela lei.

A Lei $n^{\circ} 7.210 / 1984$ foi criada face à necessidade de normatização específica acerca da problemática que envolve a execução penal, versando sobre a atuação dos órgãos administrativos, da atividade jurisdicional do Estado, e precipuamente, acerca do tratamento a ser dispensado aos condenados, impondo limites à atuação dos sujeitos participantes do processo executivo.

Com efeito, verifica-se que a Lei de Execução Penal possui a finalidade de aprimorar e dar maior efetividade ao cumprimento da pena, mas não se resume a isso, eis que se preocupa amplamente em propiciar condições básicas para o preso ou internado e também ao egresso. Além de impor ao Estado o dever de assegurar meios que proporcionem ao reeducando condições de inserção social.

\section{EXECUÇÃO PENAL GARANTISTA}

A Lei de Execuções Penais tem por objetivo assegurar ao condenado todos os direitos não atingidos pela sentença ou lei, sem distinção de natureza racial, social, religiosa ou política. Ocorre que na prática o sistema penitenciário brasileiro não está adequado às disposições de lei, desrespeitando os direitos fundamentais do condenado, afrontando diretamente as garantias constitucionais e direitos humanos. O modelo de legitimação do garantismo é congruente com o modelo democrático de Estado Constitucional de Direito, sendo um instrumento necessário para a tutela dos direitos fundamentais e indisponíveis dos seres humanos, principalmente daqueles que estão privados de sua liberdade.

O garantismo é uma teoria traçada pelo jurista italiano Luigi Ferrajoli, que busca a prote- ção da liberdade, minimizando a violência exercida pelo poder punitivo Estatal. Nas palavras de Ferrajoli (2010, p. 785-786):

Garantismo designa um modelo normativo de direito: precisamente, no que diz respeito ao direito penal, o modelo de "estrita legalidade", próprio do Estado de direito, que sob o plano epistemológico se caracteriza como um sistema cognitivo ou de poder mínimo, sob o plano político se caracteriza como uma técnica de tutela idônea a minimizar a violência e maximizar a liberdade e, sob o plano jurídico, como um sistema de vínculos impostos à função punitiva do Estado em garantia dos direitos dos cidadãos. É consequentemente, "garantista" todo sistema penal que se conforma normativamente com tal modelo e que o satisfaz efetivamente [...] Garantismo designa uma filosófica política que requer do direito e do Estado o ônus da justificação externa com base nos bens e nos interesses dos quais a tutela ou a garantia constituem a finalidade [...]

O sistema penal será garantista quando for efetivamente observado por cada um dos poderes da União. As leis que regulam a execução penal devem estar em perfeita harmonia com os princípios e normas constitucionais, sendo dever do poder Executivo criar penitenciárias condizentes para atender a demanda e os direitos dos detentos; e ao poder Judiciário o dever de sempre zelar pelas garantias e os direitos fundamentais do indivíduo para que se tenha uma verdadeira efetividade no plano fático material.

Existindo uma legislação garantista, é necessário analisar a natureza da execução penal, que de fato, é primordialmente jurisdicional - para tornar efetiva a pretensão punitiva Estatal - mas, envolve também uma atividade administrativa, já que a pena deverá ser cumprida em estabelecimentos penais regulados pelo poder Executivo.

Neste sentido o poder Executivo deve disponibilizar estabelecimentos penais condizentes com os direitos dos condenados, realidade diversa de nosso sistema penitenciário, uma vez que a superpopulação dos presídios e cadeias é alarmante, estando os condenados e os presos provisórios submetidos a condições subumanas, inobstante à legislação garantista vigente. 
A efetiva participação efetiva do poder Executivo é essencial para a promoção dos direitos e garantias dos detentos, em harmonia com os princípios constitucionais e direitos fundamentais humanos. Sem a iniciativa do Executivo, é inexequível solucionar o problema da falência do sistema penitenciário brasileiro, acabando por deixar o Judiciário impossibilitado de garantir aos condenados e aos presos provisórios os direitos previstos em lei.

Para se alcançar a tutela dos direitos humanos fundamentais, é indispensável a atuação conjunta e uniforme dos operadores do direito e o magistrado exerce função imprescindível na aplicação garantista aos direitos dos jurisdicionados, uma vez que desempenha o papel de intérprete final, incumbido pela compreensão da hermenêutica constitucional. O poder Judiciário possui o encargo de executar as leis observando e preservando as garantias e os direitos fundamentais em respeito à Constituição e aos direitos humanos.

Em contrapartida, é necessário buscar a compreensão hermenêutica de aplicação da teoria garantista de Ferrajoli, em busca de soluções no âmbito da execução penal. É dever do juiz garantista, intérprete final das leis, buscar soluções ao falido sistema penitenciário, tutelando aos apenado todos os direitos e garantias previstas no ordenamento jurídico em defesa dos direitos humanos fundamentais. Nesse sentido, assevera Cademartori (1999, p. 71): "A teoria garantista propõe-se a reconduzir as instituições do Estado à garantia dos Direitos fundamentais, propiciando um suporte teórico pra magistratura em sua função de controle independente das funções de poder."

A finalidade precípua da pena é a reabilitação dos condenados e a garantia de seu retorno à vida em sociedade. Logo, assegurar-lhes todos os seus direitos não atingidos pela sentença ou lei, sem distinção de natureza racial, social, religiosa ou política, é obrigação do Estado, que através do poder Judiciário, em unidade de propósitos com os demais poderes, devem zelar pela correta aplicação da lei.

\subsection{A atuação do juiz da execução}

A Lei de Execução Penal impõe limites à atuação do juiz para poder intervir de forma cautelar e imparcial ao velar pelo interesse das partes, de modo que o cumprimento da pena seja dado de maneira que atenda ao Ministério Pú- blico e individualizada ao reeducando, em consonância com seu progresso de ressocialização.

O artigo 66 da Lei de Execução Penal (BRASIL, 184) prevê várias atribuições ao juiz da execução, dentre as quais, destaca-se o disposto no inciso IV: "zelar pelo correto cumprimento da pena e da medida de segurança."

Sob a concepção garantista, o juiz da execução, por se tratar de um dos sujeitos principais da relação processual, detém poder geral de cautela, ficando incumbido de zelar pelo correto cumprimento da pena, coibindo excessos ou desvios, adequando o comando inicial às exigências da execução e buscando a individualização do processo executório, com a escorreita aplicação da Lei de Execução Penal e dos direitos e garantias previstos na Constituição Federal. Segundo Greco (2008, p. 11):

O juiz não é mero aplicador da lei, mero executor da vontade do legislador ordinário. Antes de tudo, é o guardião de nossos direitos fundamentais. Ante a contrariedade da norma com a Constituição, deverá o magistrado, sempre, optar por esta última, fonte verdadeira de validade da primeira.

Em uma execução penal garantista, o reeducando é reconhecido como detentor de direitos e parte dessa nova relação jurídica estabelecida por meio do título executivo originado do decreto condenatório transitado em julgado e que sustenta todos os direitos não atingidos pela decisão condenatória. Ferrajoli (2010, p. 90) anota:

A sujeição do juiz à lei já não é de fato, como no velho paradigma juspositivista, sujeição à letra da lei, qualquer que seja o seu significado, mas sim sujeição à lei somente enquanto válida, ou seja coerente com a Constituição. $\mathrm{E}$ a validade já não é, no modelo constitucionalista-garantista, um dogma ligado à existência formal da lei, mas uma sua qualidade contingente ligada à coerência - mais ou menos opinável e sempre submetida à valoração do juiz — dos seus significados com a Constituição. Daí deriva que a interpretação judicial da lei é também sempre um juízo sobre a própria lei, relativamente à qual o juiz tem o dever e a responsabilidade de 8 escolher somente os significados válidos, ou seja, com- 
patíveis com as normas constitucionais substanciais e com os direitos fundamentais por elas estabelecidos.

Contudo, a própria privação da liberdade, conforme já salientado, é, necessariamente, marcada pela legalidade que norteia a execução penal. Sendo certo que, embora privado da liberdade, o sentenciado continue a gozar de todos os outros direitos fundamentais e qualquer restrição a direito, somente será aceitável se encontrar respaldo na ordem Constitucional. 1040):

Nesse sentido leciona Nucci (2011, p.

O estudo e a aplicação das normas de execução penal devem observar os princípios constitucionais penais e processuais penais, até pelo fato de que, para realizar o direito punitivo do Estado, justifica-se, no Estado democrático de Direito, um forte amparo dos direitos e garantias individuais. Não é viável a execução da pena dissociada da individualização, da humanidade, da legalidade, da anterioridade, da irretroatividade da lei prejudicial ao réu (princípios penais) e do devido processo legal, como todos os seus corolários (ampla defesa, contraditório, oficialidade, publicidade, dentre outros).

O juiz garantista não deve aceitar o descaso administrativo do poder Executivo, que mantém estabelecimentos penais em condições precárias e detentos vivendo em condições desumanas, devendo interditá-los, e se for necessário agir nas políticas públicas. Deve exercer o papel de garantidor do sistema contra violações ou ameaças a direitos fundamentais, passando a tutelar não somente a estrita formalidade, mas todo o conteúdo previsto na Constituição, em busca de um verdadeiro Estado Democrático de Direito.

\subsubsection{Motivação das decisões judiciais}

Fundamentar significa que o magistrado deve expor as razões, de fato e de direito, que contribuíram para o seu livre convencimento para decidir a questão daquela maneira. Para o mestre Cretella Junior (2006, p. 32): "A fundamentação ou motivação das decisões judiciais é onde se encontram expostas as bases lógico-jurídicas do julgamento, as premissas claramente fixadas e o enquadramento dos fatos nos dispositivos legais pertinentes."

Versando as decisões do juiz da execução acerca de direitos indisponíveis do apenado, eis que é competente para deliberar acerca dos incidentes de progressão e regressão de regimes, concessão ou revogação do sursis, concessão ou revogação do livramento condicional, imperiosa se faz a motivação de seus atos decisórios, garantindo, antes de tudo, o direito ao contraditório e a ampla defesa ao condenado e o estabelecimento do devido processo legal na esfera executiva, em conformidade com o artigo $5^{\circ}$, inciso LIV e LV, ambos da Constituição Federal. A fundamentação tem repercussão fundamental e não meramente formal, deste modo o juiz deve analisar as questões levadas a seu julgamento, exteriorizando a base fundamental de suas decisões.

Para o professor Misael Montenegro FiIho (2015, p. 73):

Em qualquer hipótese, o magistrado deve revelar quais os argumentos apresentados pelo autor que o convenceram do preenchimento dos requisitos específicos, apoiando a sua decisão em fatos do processo, além dos documentos atados à petição inicial. A decisão que não apresenta essa característica é nula, por afrontar o princípio constitucional estampado no inciso IX do art. 93 do Texto Maior, que assegura a transparência das decisões judiciais, infringindo, além disso, o princípio do devido processo legal, o que pode e deve ser reconhecido de ofício pelo tribunal, por ser como matéria de ordem pública, transpassando o interesse meramente particular das partes. A nulidade da decisão judicial, pela falta ou pela deficiência de fundamentação, não se confunde com a decisão judicial equivocadamente fundamentada, que não é marcada pela nulidade, devendo ser apenas corrigida, adequando-se aos fatos e aos argumentos jurídicos invocados pelas partes. Essa Consideração é importante, já que a existência de fundamentação, embora equivocada, não dá cabimento à interposição de recurso extraordinário, à mingua de infração à disposição da CF.

A decisão judicial é perfeitamente fundamentada com menção a parecer jurídico constante dos autos, ou às alegações das partes, 
desde que nessas manifestações sejam expostos valores sobre provas e questões submetidas a julgamento.

A jurisprudência tem se voltado, até por força constitucional, a considerar que a ausência de fundamentação dos atos decisórios, judiciais e administrativos gera, de maneira imperdoável, a consequente nulidade do pronunciamento judicial.

Tal padrão técnico deve buscar embasamento em outro de cunho ainda mais específico que é a garantia da ponderação e lisura do julgamento por parte do magistrado, impondo limites à sua arbitrariedade, vez que, antes de tudo, deve atuar como fiscal da lei, revelando-se imparcial.

\subsection{A atuação do Ministério Público}

O Ministério Público, por se tratar do titular da ação penal pública e responsável pela fiscalização da lei, na esfera executiva atua como parte essencial, zelando pelo correto cumprimento da pena, de maneira a atender a pretensão punitiva estatal materializada na sentença e assegurando um processo de execução mais individualizado possível ao reeducando, em consonância com seus avanços e progressos, assegurando o estabelecimento do devido processo legal.

Incumbe ao Promotor de Justiça, além do papel de fiscal da lei, atuar como parte imparcial no processo executivo (custos legis), quando versar sobre direitos e garantias fundamentais inerentes ao apenado, como por exemplo no caso de reconhecimento do benefício remição, da progressão de regime, no caso de concessão de livramento condicional. Como também, deve atuar de maneira parcial, demandando em desfavor dos interesses do condenado, como ocorre nos incidentes de regressão de regime e revogação de benefícios.

Consoante dispõe o artigo $1^{\circ}$ da Lei Orgânica do Ministério Público n 8.625/1993 e o artigo 127, caput, da Constituição Federal, o Ministério Público é instituição permanente, imprescindível à função jurisdicional do Estado, responsável por tutelar a defesa da ordem jurídica e pública e dos interesses individuais e coletivos indisponíveis.

O artigo 68 da Lei de Execução Penal (BRASIL, 1984) prevê várias atribuições ao Ministério Público, dentre as quais, destaca-se o disposto no inciso II: "II - requerer: a) todas as providências necessárias ao desenvolvimento do processo executivo."

Compete ao Ministério Público ingerir-se durante toda a fase de execução da pena, postulando pelas providências necessárias ao desenvolvimento de todas as fases do processo executivo. Sua atividade de fiscalização pode, inclusive, legitimá-lo a postular em favor do executado. Ser garantista não é uma opção do membro do Ministério Público, mas um dever pelo qual ele jurou solenemente fidelidade no ato de sua posse.

Com efeito, cumpre destacar que as atribuições processuais e extraprocessuais do Promotor de Justiça com atribuições na execução penal devem ser executadas com a observância do padrão de racionalidade, de justiça e de legitimidade da intervenção punitiva, proposto pela Constituição da República.

É preciso, pois, que a atuação do Ministério Público seja voltada para uma solução penal mais adequada, justa e equilibrada, em consonância com o preceitos legais contidos na Lei de Execução Penal, de maneira a se garantir o controle da criminalidade face a aplicação correta e satisfatória da Lei.

\subsection{A garantia do devido processo legal}

O Princípio do Devido Processo Legal é uma garantia constitucional prevista no artigo $5^{\circ}$, inciso LIV, da Carta Magna (BRASIL, 1988):

Art.5 $5^{\circ}$ Todos são iguais perante a lei, sem distinção de qualquer natureza, garantindo-se aos brasileiros e aos estrangeiros residentes no país a inviolabilidade do direito à vida, à liberdade, à igualdade, à segurança e à propriedade, nos termos seguintes:

LIV- ninguém será privado da liberdade ou de seus bens sem o devido processo legal.

Ele é a base legal para aplicação de todos os demais princípios, independente do ramo do direito processual, eis que garante a eficácia dos direitos coletivos e individuais indisponíveis estabelecidos pela nossa Constituição Federal, por meio do estabelecimento de um processo justo e devido, impedindo decisões voluntaristas e arbitrárias.

Sobre o tema, Paulo Henrique dos Santos Lucon (1999, p. 45) diz que:

A cláusula genérica do devido processo 
legal tutela os direitos e as garantias típicas ou atípicas que emergem da ordem jurídica, desde que fundadas nas colunas democráticas eleitas pela nação e com o fim último de oferecer oportunidades efetivas e equilibradas no processo. Aliás, essa salutar atipicidade vem também corroborada pelo art. $5^{\circ}, \S 2^{\circ}$, da Constituição Federal, que estabelece que "os direitos e garantias expressos nesta Constituição não excluem outros decorrentes do regime e dos princípios por ela adotados, ou dos tratados internacionais em que a República Federativa do Brasil seja parte.

O devido processo legal resguarda as partes de atos arbitrários das autoridades jurisdicionais e executivas, garantindo aos jurisdicionados um julgamento justo e igualitário com atos e decisões devidamente motivadas.

Tratando-se de um preceito fundamental, do qual decorrem todas as demais garantias constitucionais, sua aplicação ao processo de execução penal trata-se de uma consequência lógica, vez que o agente, alvo de uma condenação, sofrerá coercitivamente restrições aos seus direitos e liberdades, de maneira que o Estado, ao demandar contra e a favor dos interesses do apenado, deverá assegurar a ele todos os direitos não atingidos pela decisão condenatória e pela lei.

O processo de execução penal existe para servir ao condenado e a sociedade. O condenado é parte da relação jurídica que mais carece de um processo de execução devido, pois tem todos os seus direitos restringidos coercitivamente pelo Estado. Por outro lado, para que a sua reabilitação e ressocialização aconteça, a sociedade também reclama um processo de execução devido, para que o retorno desse individuo ao convívio coletivo esteja permeado de expectativas de não-reincidência e desenvolvimento de suas potencialidades como pessoa de bem.

A excessiva formalidade e burocracia do sistema de justiça criminal brasileiro é impeditiva do estabelecimento de um devido processo na execução penal, uma vez que o juiz da execução, longe da concepção garantista, acaba atuando sob o manto da neutralidade política, não se atentando que a reforma penal somente existirá quando a vontade política nos textos legais inovadores se tornar exequível.

\section{ESTABELECIMENTOS PENAIS COMO OBS- TÁCULO PARA EFETIVA EXECUÇÃO PENAL}

Os estabelecimentos penais, dispostos nos artigos 87 a 104 da Lei de Execução Penal, são aqueles utilizados pela justiça com o objetivo de alojar indivíduos presos, sejam provisórios ou condenados, ou ainda aqueles submetidos às medidas de segurança.

De acordo com a pena imposta e o regime de cumprimento aplicado, os presos são destinados e recolhidos em Penitenciárias: estabelecimentos fechados, geralmente para condenados e também de segurança máxima; Cadeias Públicas: servem para a custódia do provisório e cumprimento de pena breve; Colônias Agrícolas e Industriais: para presos que cumprem pena em regime semiaberto; Casa do Albergado: para presos que cumprem pena em regime aberto e Hospital de Custódia e Tratamento Psiquiátrico: destina-se a inimputáveis e semi-imputáveis, que dependem de tratamento de substâncias químicas. Embora a preocupação da LEP em dar efetividade ao cumprimento da pena imposta com o recolhimento do condenado ou o agente do delito em local adequado à sua condição, a infraestrutura do sistema prisional brasileiro não conseguiu se adequar ao modelo imposto por ela. Veja-se, em alguns estados brasileiros tampouco existe a Casa do Albergado, em outros, as Colônias Agrícola e Industriais são insuficientes, face a crescente população de apenados, submetendo os presos provisórios ao convívio com os condenados definitivamente. Nesse sentido, Norberto Avena (2014, p. 65) assevera:

Infelizmente, no Brasil a realidade carcerária corre à revelia dessa normatização, caracterizando-se muitas de nossas penitenciárias como ambientes absolutamente insalubres, onde se concentram, na mesma cela, número de presos superior à sua capacidade, prejudicando sensivelmente o processo de readaptação do preso à sociedade. Consequência dessa situação desastrosa que atinge o preso é a criação de ambiente negativo ao reajustamento, facilitando a reincidência criminosa que, bem sabemos, atinge níveis alarmantes no país.

A precariedade e as condições subumanas que os detentos vivem hoje é de alarmante 
violência. Os presídios se tornaram depósitos humanos, onde a superlotação acarreta violência sexual entre presos, faz com que doenças graves se proliferem, as drogas cada vez mais são apreendidas dentro dos presídios, e o mais forte detém poder sobre o mais fraco.

Segundo último levantamento realizado pelo Depen - Departamento Penitenciário Nacional- no ano de 2014 a população carcerária do Brasil alcançou a quarta posição no ranking mundial, superando países muito mais populosos, como a Índia, que tem seis vezes mais habitantes que o Brasil. A superlotação é um dos principais problemas que atinge os sistemas penitenciários, a população encarcerada aumenta anualmente sendo que o número de estabelecimentos prisionais não é capaz de acompanhar essa demanda populacional.

A superlotação tem grande influência no desenvolvimento do tratamento do apenado e a problemática da carência de vagas se interliga com a reincidência, já que só aumenta vertiginosamente no nosso sistema penal. Em razão disso, os apenados são submetidos ao cumprimento de suas penas em razões subumanas, sendo amontoados em unidades, expondo a riscos sua integridade física e moral e, consequentemente, dificultando, as ações voltadas para a melhoria do cumprimento de pena sob vários aspectos.

A precariedade dos estabelecimentos prisionais reflete nas condições de higiene dos presos, no despreparo dos funcionários, que em sua maioria são pessoas não qualificadas e capacitadas para poderem pôr em prática trabaIhos necessários voltados a ressocialização dos apenados e uma série de fatores que apontam a falência do sistema. Como afirma Mirabete (2002, p. 24):

A ressocialização não pode ser conseguida numa instituição como a prisão. Os centros de execução penal, as penitenciárias, tendem a converter-se num microcosmo no qual se reproduzem e se agravam as grandes contradições que existem no sistema social exterior (...). A pena privativa de liberdade não ressocializa, ao contrário, estigmatiza o recluso, impedindo sua plena reincorporação ao meio social. A prisão não cumpre a sua função ressocializadora. Serve como instrumento para a manutenção da estrutura social de dominação.
Embora a Lei $n^{\circ} 7.210 / 84$ seja uma das leis mais completas e eficientes do mundo, em contrapartida o ambiente carcerário acaba sendo um meio falido para reabilitar o recluso devido às condições materiais e humanas das prisões, que impedem a realização do objetivo reabilitador. Sobre o tema, leciona Nucci (2011, p. 27):

[...] na prática, lamentavelmente, o Estado tem dado pouca atenção ao sistema carcerário, deixando de lado a necessária humanização do cumprimento de pena, em especial no tocante à pena privativa de liberdade, permitindo que muitos presídios se tenham transformado em autênticas masmorras, bem distante do respeito à integridade física e moral dos presos, direito constitucionalmente imposto.

Com efeito, não se pode aventar que a falência do sistema prisional brasileiro é consectária apenas da falta de investimento público na construção de mais estabelecimentos prisionais, mas também da falta de políticas públicas no implemento de penas alternativas e atividades menos incisivas de punição, no âmbito profissional e educacional, visando ao melhor aproveitamento do tempo que o apenado passa dentro das prisões, bem como no preparo e qualificação dos agentes que trabalham nas instituições prisionais, de modo que possam servir de instrumentos para a colocação do preceitos da LEP em prática e, por consequência, no estabelecimento de uma execução penal devida e satisfatória. Segundo afirma Zacarias (2006, p. 35):

Apesar de moderna, procurando racionalizar, desburocratizar e flexibilizar o funcionamento do sistema prisional, a Lei de Execuções Penais não tem produzido os resultados concretos almejados por seus autores e esperados pela sociedade. Tal ineficácia está na omissão do Poder Executivo que, procurando de todas as formas dirimir e eximir-se de suas obrigações básicas no plano social, até a presente data não houve investimentos necessários em escolas, em fábricas e fazendas-modelo, ou mesmo comércio; em pessoal especializado e em organizações encarregadas de encontrar postos de trabalho para os presos em regime semiaberto e aberto, principalmente para os egressos dos es- 
tabelecimentos penais.

Enquanto o Estado não se atentar de que o sistema carcerário brasileiro encontra-se falido e pedindo socorro, suas mazelas continuarão se reproduzindo e atingindo toda a sociedade, a qual nunca será capaz de deixar de estigmatizar o condenado, rejeitando-o e colocando-o à margem do convívio social. Por sua vez, o condenado e o egresso também não conseguirão se desvincular do submundo do crime em que se inseriram, fazendo com que retornem as prisões por falta de amparo da sociedade e da falta de assistência do Estado.

\section{REINCIDÊNCIA CRIMINAL CONSEQUÊN- CIA DA INADEQUADA EXECUÇÃO PENAL}

A reincidência é o principal fator da deficiência de qualquer sistema de atendimento jurídico-social, porque por meio dela é possível perceber que as pessoas entram nas instituições por apresentarem certas carências, que vão desde deficiência na escolaridade, ausência de qualificação profissional ou de caráter e personalidade, até a falta de moradia digna, e que, independente do tempo que tenham passado sob os cuidados das instituições, ao cumprirem suas penas e saírem apresentam as mesmas deficiências que originaram sua entrada no sistema.

A Lei de Execução Penal tomou um cuidado especial ao tutelar sobre os direitos e garantias tanto dos condenados que ainda cumprem pena, quanto dos egressos. Consoante dicção expressa do artigo 10 da Lei de Execução Penal (BRASIL, 1984):

\section{Art. 10. A assistência ao preso e ao in- ternado é dever do Estado, objetivando prevenir o crime e orientar o retorno à convivência em sociedade. \\ [...] \\ Parágrafo único. A assistência estende- -se ao egresso.}

Embora a LEP seja perfeita em seu plano ideal, sua aplicação fica limitada ao plano fático material, uma vez que a crise do sistema prisional brasileiro e a omissão estatal, como visto anteriormente, dificultam o alcance da norma jurídica em sua integralidade, de modo que os princípios e garantias fundamentais inerentes aos jurisdicionados no processo de execu- ção, sejam deixados de lado ante a ausência de meios para proporcioná-los.

Com efeito, o sistema que deveria procurar resolver de forma efetiva as deficiências apresentadas pelos condenados, acaba, em contrapartida, exercendo sobre eles apenas um controle jurídico e burocrático, devolvendo-os ao meio social sem que tenham sido reabilitados. Sobre o tema Mirabete explana (2002, p. 23):

O direito, o processo e a execução penal constituem apenas um meio para a reintegração social, indispensável, mas nem por isso o de maior alcance, porque a melhor defesa da sociedade se obtém pela política social do estado e pela ajuda pessoal.

Assim, a ressocialização buscada no sistema penitenciário acaba comprometida, abnegando ao condenado o seu direito constitucional a individualização da pena, distante de um tratamento humanitário devido, voltado às oportunidade de reinserção na sociedade, saindo de lá pior do que entrou. Para Rogério Greco (2008, p. 611): "A reincidência é a prova do fracasso do Estado na sua tarefa ressocializadora."

A recuperação do apenado se dá mediante medidas que auxiliem na sua educação, conscientizado psicologicamente e socialmente, medidas essas que reduzem os níveis de reincidência. Contudo, o serviço público que serve para atender os egressos não consegue atender mais da metade da demanda, deixando muitas pessoas e suas famílias desamparadas, à mercê da própria sorte. Sabe-se que muitas das pessoas que saem da prisão cometem outro delito em um pequeno intervalo. Esse fator apresenta um círculo vicioso de contínuas entradas e saídas dos serviços públicos de assistência a população.

O sistema prisional carece de investimentos em material humano preparado e instruído, abrangendo desde a atividade do diretor dos estabelecimentos penais, que deveria empreender melhorias na administração da unidade prisional, implantando e colocando em prática políticas e diretrizes referentes a execução de pena; como também, maior número de profissionais qualificados, importantes para elaboração de pareceres diários no que tange à saúde, na solução de demandas pessoais, estabelecendo um vínculo entre o apenado dentro do presídio 
e após fora dele. Os servidores em geral, médicos, psicólogos, advogados deveriam atuar em unidade de propósitos com aos agentes penitenciários, envolvidos pelos mesmos objetivos: o bom andamento dos trabalhos e a reabilitação dos apenados.

Aliado a isso, falta por parte do Estado a implementação de cursos profissionalizantes preparatórios para inserção do apenado no mercado de trabalho, conferindo melhor aproveitamento do tempo ocioso do apenado e com a finalidade equilibrar a disparidade social, que é um dos possíveis fatores geradores da criminalidade. No que tange à educação, falta maior incentivo ao apenado à escolarização, oportunizando a potencialização de suas capacidades intelectuais, possibilitando sua escolarização completa e, inclusive, ser futuramente inserido no Ensino Superior, já que a maioria não foi submetida ao ensino educacional desde infância, adolescência e até mesmo em fase adulta.

Consoante depreende-se da LEP, deve ser garantido aos egressos do sistema prisional a orientação e apoio para reintegrá-lo à vida em liberdade. Estabelece a lei, que o Estado deve garantir ao egresso a assistência social e material. Todavia, diante de todas as deficiências elencadas, a ausência de projetos de recuperação e a consciência de que a sociedade já o estigmatiza, o objetivo principal da pena, que é a recuperação do agente delinquente, acaba frustrado, uma vez que o apenado acaba saindo da instituição prisional pior do que entrou: totalmente aliciado pelas facções criminosas que dominam os estabelecimentos penais e mais vinculado à criminalidade e com carências e demandas maiores, uma vez que são expostos a condições subumanas e degradantes. Sofrem ainda exposição de sua saúde física e mental diariamente, demonstrando a decadência do sistema prisional brasileiro, que ao invés de servir como instrumento de legitimação do poder do Estado face as condutas desviantes e ilícitas, acabou se tornando uma escola que favorece a criminalidade.

Com feito, nota-se a Lei de Execução Penal não precisa de outras leis que a complementem, que serviriam para burocratizar ainda mais o sistema judiciário e penal, o problema está na não efetivação do mínimo contido em lei em prática.

\section{CONSIDERAÇÕES FINAIS}

Embora considerada uma das legislações mais modernas do mundo, a Lei de Execução Penal $n^{\circ} 7.210 / 1984$ enfrenta muitos obstáculos na aplicação de seus dispositivos.

O sistema penal brasileiro ainda não vivenciou o garantismo em sua integralidade, e o titular da ação penal pública tem muito a ver com esse quadro, vez que é seu dever não apenas atuar como fiscal durante todo o processo de execução da pena, mas também opor soluções adequadas e racionais para o estabelecimento de um processo devido, resguardando ao jurisdicionado o respeito e a tutela de todos os direitos e garantias indisponíveis inerentes a ele.

O juiz da execução, por sua vez, tratando-se de parte imparcial e mediador dos interesses das partes da relação jurídica existente nessa fase processual: apenado e Estado, tem por objetivo assegurar o atendimento diligente do comando contido na sentença condenatória prolatada, a fim de satisfazer a pretensão punitiva estatal, bem como possui o dever de propiciar ao condenado um cumprimento de pena individualizado, resguardando-lhe todos os direitos não atingidos pela sentença ou lei, sem distinção de natureza social, racial, política e religiosa.

A dignidade no tratamento dos indivíduos na qualidade de seres humanos é um direito inerente a todos, sem distinção quanto a sua condição. Por esse motivo é obvia a necessidade de sua proteção durante todo processo de execução da pena. O modelo de legitimação do garantismo possui congruência com os preceitos do Estado Democrático de Direito, sendo um instrumento necessário para a tutela dos direitos substanciais e indispensáveis dos indivíduos, precipuamente daqueles que sofreram privação de sua liberdade.

Embora a Lei de Execução Penal seja perfeita em seu plano ideal e jurídico, preconizando a necessidade de investimentos pelo poder público no sentido de prestar a devida assistência ao preso e também ao egresso, a ineficiência do sistema prisional brasileiro e o descaso do poder estatal acabam por obstaculizar sua aplicação do plano fático real, no que tange à ressocialização do detento, a falta de programas voltados para este mister, acaba sobrando ao Juiz da execução, por meio de sua atividade jurisdicional tentar empreender melhorias para a efetiva reeducação do apenado, cumprindo a lei 
em sua íntegra a fim de se inibir sua possível reincidência e oferecer condições satisfatórias para seu retorno à sociedade.

Embora a Lei de Execução Penal preconize a necessidade de investimentos pelo poder público no sentido de prestar a devida assistência ao preso e também ao egresso, a efetivação dos preceitos contidos na referida lei não estão sendo colocados em prática em sua totalidade, principalmente no que se refere à assistência do reeducando e do egresso ao retorno ao mercado de trabalho, a fim de que a temida reincidência criminal seja elidida.

O cumprimento da LEP já seria suficiente para melhorar o sistema carcerário no Brasil. Logo, não há a necessidade de criação de mais leis, que só serviriam para burocratizar ainda mais o sistema judiciário e penal. Deve-se concentrar todos os esforços para o efetivo cumprimento da lei vigente, que é a Lei de Execução Penal.

\section{REFERÊNCIAS}

ASSIS, R. D. de. A realidade atual do sistema penitenciário brasileiro. Brasília: Revista CEJ, 2007.

AVENA, N. C. P. Execução penal: esquematizado. São Paulo: Forense, 2014.

BRASIL. Constituição Federal de 1988. Promulgada em 5 de outubro de 1988. Disponível em: <http://www.planalto.gov.br/ccivil_03/ constituicao/constituição.htm>. Acesso em: 31 jul. 2017.

Lei $n^{\circ}$ 7.210, de 01 de julho de 1984. Institui a Lei de Execução Penal. Disponível em: <http://www.planalto.gov.br/ccivil_03/leis/L7210. htm>. Acesso em: 31 jul. 2017.

CADEMARTORI, S. Estado de direito e legitimidade: uma abordagem garantista. Porto Alegre: Livraria do Advogado, 1999.

CRETELLA JUNIOR, J. Comentários à Constituição Brasileira de 1988. 2. ed. Rio de Janeiro: Forense Universitária, 2006.

FERRAJOLI, L. Direito e Razão: teoria do garantismo penal. 3. ed. São Paulo: Revista dos Tribunais, 2010.
GRECO, R. Código Penal Comentado. Niterói: Impetus, 2008.

LUCON, P. H. dos S. Garantia do tratamento paritário das partes, Garantias constitucionais do processo civil. São Paulo: Revista dos Tribunais, 1999.

MARCÃO, R. Curso de Execução Penal. 2. ed. São Paulo: Saraiva, 2005.

MIRABETE, J. F. Execução Penal. 10. ed. São Paulo: Atlas, 2002.

Atlas, 2007.

Execução penal. 11. ed. São Paulo:

MONTENEGRO FILHO, M. Curso de Direito

Processual Civil. 11. ed. São Paulo: Atlas, 2015.

NUCCI, G. de S. Manual de execução penal. 8. ed. São Paulo: Revista dos Tribunais, 2011.

SANTOS, P. F. Aspectos Práticos da Execução

Penal. São Paulo: Universitária de Direito. 1998.

\section{LA EJECUCIÓN DE LA PENA Y SUS PERCANCES JURÍDICOS}

Resumen: Delante la necesidad de normalización específica acerca de la problemática que involucra la ejecución penal, en 11 de julio de 1984, el legislador instituyó la Ley de Ejecución Penal $n^{\circ} 7.210$, con el objetivo de establecer directrices para atención de las disposiciones de la sentencia o decisión criminal y proporcionar condiciones para la integración social del arrestado y del ingresado, imponiendo deberes al Estado. Todavía, la situación del sistema penal brasileño se presenta como uno de los grandes obstáculos para la aplicación de los preceptos contenidos en la Ley. La superpoblación de los presidios y cárceles y la falta de políticas públicas que busquen medidas alternativas al encarcelamiento, acaban frustrando el proceso de rehabilitación del apenado, desencadenando en la sociedad un sentimiento de rechazo cuanto a ese individuo e influenciando su vuelta a la criminalidad. La adopción de un modelo de ejecución penal garantista sería la solución para ese sistema fallido, en el cual el Poder Ejecutivo, en unidad de propósitos con los operadores del derecho, actuarían de forma conjunta en el empleo de mejorías al proceso ejecutivo, promoviendo satisfacción de la pretensión punitiva estatal buscada en la sentencia y asegurando al apenado todos sus derechos y garantías constitucionales señalados en la LEP, de manera a suplir sus carencias. La reincidencia criminal solamente será elidida cuando 
SERAFIM, G.; REMOR, R.; FENATO, C. S. da P. M.

el Estado posibilitar medios para la rehabilitación y resocialización del apenado.

Palabras clave: Debido Proceso Legal; Ejecución

Penal Garantista; Ley de Ejecución Penal;

Reincidencia. 